\title{
Development of a Science Module through Interactive Whiteboard
}

\author{
P. Thivilojana S. Perinpasingam ${ }^{1}$, Nalini Arumugam ${ }^{2}$, Sathyaperbha Subramaniam ${ }^{2} \&$ Gopighantan \\ Mylvaganam $^{2}$ \\ ${ }^{1}$ School of Architecture, Buiding \& Design, Taylor's University, Subang Jaya, Malaysia \\ ${ }^{2}$ Akademi Pengajian Bahasa, Universiti Teknologi Mara, Shah Alam, Malaysia \\ Correspondence: P. Thivilojana S. Perinpasingam, School of Architecture, Buiding \& Design, Taylor's \\ University Lakeside Campus, 47500 Subang Jaya, Selangor Darul Ehsan, Malaysia. E-mail: \\ lojana.sp@gmail.com
}

Received: May 12, 2014 Accepted: July 9, 2014 Online Published: August 15, 2014

doi:10.5539/res.v6n3p31 URL: http://dx.doi.org/10.5539/res.v6n3p31

\begin{abstract}
This study reveals the outcome of the design and evaluation module using Interactive Whiteboard in the teaching and learning of Science in a Year Three classroom. The development process was based on Kristaf and Satran's (1995) notion that information, interactive and presentation designs form the system of interactive learning. Besides, the design model by Dick and Carey (1990) describes that evaluation and the revision processes were directed concurrently. Two instructional technologists and content experts participated in assessing the efficacy of this module. It is concluded that the module supports interactive learning approaches. The module served as a pedagogical tool that seems to be a feasible solution to heightening the inquisitive learning of science and confidence of primary school children.
\end{abstract}

Keywords: interactive whiteboard, module development and instructional technology

\section{Introduction}

The science curriculum at the primary level in Malaysia view children as those who can experiment, discover and solve logical problems. Here, the teacher is expected to guide, counsel and facilitate the students with minimal influence, emphasizing on critical thinking and scientific skills of these students. These also include science processes and manipulative skills. In order to have an effective teaching and learning of science, the teacher must be well-versed in the subject matter. However, it was found that the teachers' pedagogical and content knowledge of science to be inadequate, Hashimah and Raper (2007).

It is apparent that these teachers value the processes and concepts interaction in the teaching and learning of science. This is nevertheless hindered by their insufficient pedagogical knowledge of this subject. They encounter problems in encouraging a two-way interdependence among pupils in making them understand the surroundings as well as the scientific processes.

According to Hashimah and Raper (2007), there are several reasons why teachers lack pedagogical knowledge in Science. Firstly, the teaching approach used in science classes shows inconsistencies between the objectives of curriculum and the patterns of actual classroom interaction. These inconsistencies influence the execution of the curriculum as intended by the Ministry of Education. Secondly, the study on the teaching and learning of science reveals that the academic achievement of pupils is the main priority of teachers' intended outcome. Thus, the teachers neglect other significant outcomes of learning this subject. Thirdly, there is a discrepancy between the roles teachers assume in their classroom and their desired roles.

At this juncture, Interactive Whiteboards are becoming increasingly popular in international educational environments. It was reported during a keynote address at the 2008 Australian Computers in Education Conference that, interactive whiteboards are currently being used in over $99 \%$ of schools in United Kingdom (Cox, 2008). The technology is now being introduced into Australian schools, and educators are questioning how the technology can be used to support learning and teaching. Besides, researchers (Kaur \& Rashid, 2012; Singh, Omar, \& Anuar, 2010) disclosed that Interactive Whiteboard not only motivates students but also engages them in the teaching and learning process. They also highlighted that students interact more actively in classrooms where technology is used effectively. Smith, Higgins, Wall \& Miller (2005) also established the idea of interactive pedagogy using the interactive whiteboard. 
This brings about 'interactive teaching' pedagogy, where higher order thinking skills are used in the teachers' methods of questioning. Pupils' active participations are appreciated when teachers evaluate their pupils' progressive understanding against holistic meaning (Jones \& Tanner, 2002).

Interactive Whiteboard can enhance interactive teaching and learning by providing an avenue for pupils to express their views openly with confidence. The Interactive Whiteboard also offers collaborative opportunities for reasoning, sharing of ideas, and to negotiate new meanings based on the viewpoints of others (Rogoff, 1995).

The integration of information and communication technology into science classrooms is becoming increasingly important in engaging and motivating today's students. To improve teaching and learning, Hackling and Prain (2006) found that 'Information and Communication Technologies (ICT) are exploited to enhance learning.' (p. 19). Educational research has suggested that it is possible to integrate ICT effectively into classrooms with the use of interactive whiteboard technology (Riel, Schwarz, Hitt, 2002; Shenton \& Pagett, 2007; Murcia, 2007). Schuck and Kearney (2007) investigated the use of Interactive Whiteboard in K-12 pedagogy in some primary and secondary schools. The teachers, students and school executives participating in this research acknowledged that the Interactive Whiteboard is user-friendly, facilitates reflective practice as well as assists to discover and learn new skills. An important point was also revealed that the Interactive Whiteboard acts as a catalyst for teachers, and as for students, it matches their digital culture. In Malaysia, the literature has not paid sufficient attention to designing interactive modules, especially in the teaching of science among primary school children. Technology has aggressively invaded the classrooms, competing against traditional pedagogical practices. Teachers are faced with the perennial challenge on how to provide a depth and breadth of the subject matter in order to create 'informed citizens' in primary schools. Instead of being intimidated by technology, teachers have to be computer savvy; capable of using electronic mail and surfing the Internet to find sources for their science lessons. Hence, due to its visual presentation and its interactive attributes, the Interactive Whiteboard is a preferred multimedia instruction.

An Interactive Whiteboard can be exploited to manoeuvre texts and images. It also allows saving of notes for review, printing of these notes and also sharing them among group members using the Internet.

The incorporation of digital-based activities with templates and images as well as making use of presentation tools in this Interactive Whiteboard software enhances the learning resources

(Smart Technologies Inc., 2004). Such experiential learning does not take place in chalk and board method or even by using overhead projector.

\section{Problem Statement}

Norrizan Razali (2002) stated that the concept of smart teaching and learning would feature the students' abilities to get information themselves. The government has spent millions of ringgit for the smart school projects by furnishing the schools with computers and Internet connection. Jamerson (2002) stated that using Interactive Whiteboard as a teaching instrument will multiply students' motivation to learn through collaborative teaching and learning in a classroom. In order to make science an interesting and enjoyable lesson, the Ministry of Education have suggested numerous teaching and learning methods such as experiments, demonstrations and simulations. Many parents and members of the public tend to blame the teachers of their incompetent methods of teaching when students are incapable of acquiring the knowledge or skills taught. This is simply because most of the activities are not stimulating and the students are unable to comprehend what the teachers have delivered. Nevertheless, the main idea for using Interactive Whiteboard in a classroom is to offer substantial hands-on opportunities to work with multimedia expedients (Smart Technologies Inc., 2004). Therefore, it advocates interaction among students; regardless in teacher-directed or group-based learning, thus creating experiential learning, which concurs with Beeland (2002). Apart from that, a module will not be effective without a proper pedagogical aspect and instructional design. Ismail (2002) stated that the smartness of an instruction depends on how far the teacher conforms to the pedagogical, psychological and technology in the process of delivering knowledge in order to generate intellectual students.

\section{The Purpose and Scope of the Study}

The aim of this study was to investigate the criteria involved in the designing and evaluating a module using an Interactive Whiteboard in the teaching and learning of Science in a Year 3 classroom besides eliciting experts' opinion on using the module. It is also intended to be a guide for teachers to design and develop a good instructional material using the Interactive Whiteboard. This study can offer helpful tips to determine the facets and traits that are essential in developing and designing a teaching and learning material. Therefore, this study will focus on accomplishing this research niche. What are the processes or criteria involved in designing an Interactive Whiteboard? According to Beeland (2002), the Interactive Whiteboard constitutes various ways of 
administering instructions, which may be characterized into three modalities of learning. The first modality is visual learning. This method not only uses texts and pictures but also animation and video. The second technique, auditory learning, uses words orally for pronunciation and listening to sounds. The third modality of learning is tactile, which is more concrete and tangible. Beeland further points out that, when tactile learners are allowed to interact with the board physically, their learning needs can be achieved.

Therefore, incorporating these three modalities in a module or for a lesson in a classroom will enable students to be engaged in the learning process as well as increase their motivation level. Apart from that, Chandler (2005) clarifies that the use of multiple media by teachers provides them opportunities to meet the demands of students with numerous learning styles.

Kristof and Satron (1995) mentioned that the design process of an interactive learning system can be separated into three elements, namely Information, Interactive and Presentation Designs. Together with the evaluation of a module, this system can create an interactive learning atmosphere. Interaction Design focuses on guidance provided to users in order to familiarize them to scroll for any information required, while Presentation Design includes screen layout, background colour, font size as well as the use of graphs and animations.

\subsection{Information Design}

Information Design includes the aim and the learning outcome of the lesson, the content and the clarity of instruction given. Evaluation of a module deals with formative, which aims at refining the materials of a module, and summative, which measures the existing achievement. Therefore, this study is undertaken to explain the processes involved in designing the module using the Interactive Whiteboard. The experts' views with regards to the development and evaluation of this module to teach science using the Interactive Whiteboard will be discussed. In Malaysia, the literature has not paid sufficient attention to designing interactive modules, especially teaching science among primary school children. Therefore, it is vital to design an appropriate module to teach science in Malaysian primary schools. The theoretical framework and methodology for the interactive whiteboard to teach Science to Year Three students is based on Dick and Carey Design Model. This design model analyses the subject, the characteristics of the learners and the learning objectives.

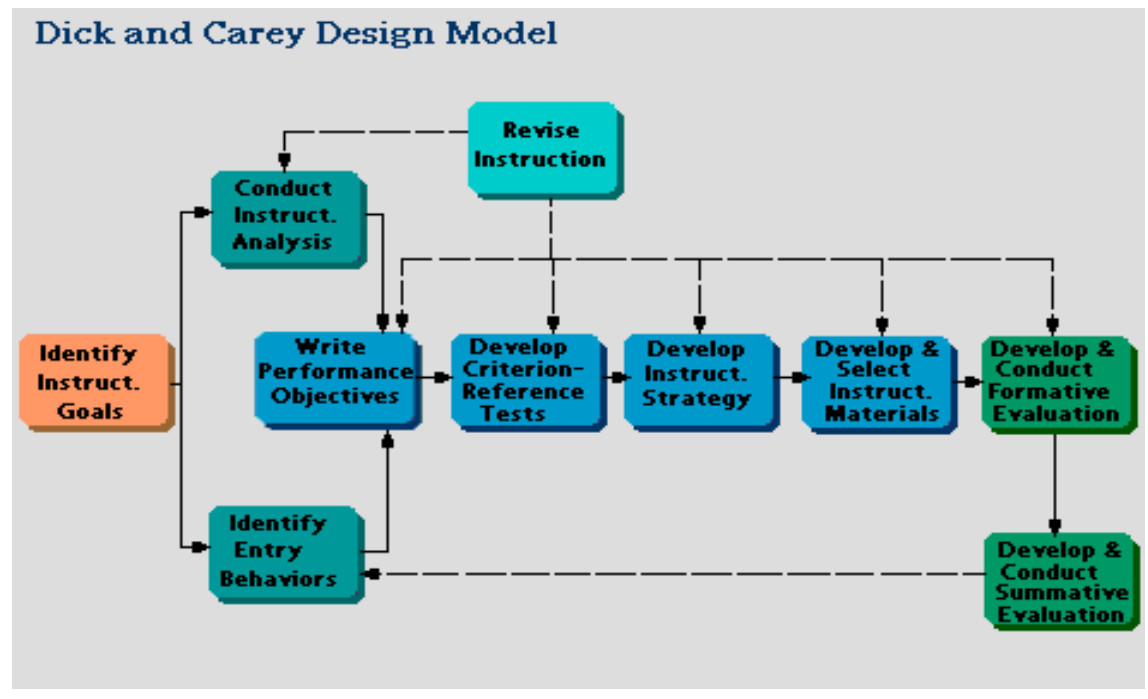

Figure 1. Dick and Carey design model

Source: http://www.coe.ecu.edu/lsit/colaric/KB/DickCarey.html

The first stage, which is known as Identifying Instructional Goals, discusses the module that the target learners are going to learn. Since the title of the module is "Plants", the students will be first briefed on sub-topics which were derived from the Year Three Science syllabus. The next step, which is not included in Dick and Carey's model, is carrying out Needs Analysis. It is incorporated in the design activities in order to identify the needs of the target learners.

Therefore, an interview with the Headmistress was conducted. Findings from the informal interview were analyzed. It was found that teachers had been trained to use the Interactive Whiteboard by the vendor. 
Other than that, this instrument can be utilized as another form of media for teaching and learning which is available in this school. Furthermore, it can promote and engage the learners as well as give a variance to the lesson. The following step is to Identify Entry Behaviour. Five Year 3 students were given a print-based activity to gauge their standard and knowledge in the topic. The fourth step involves the Writing of the Performance Objectives. These objectives specify descriptions to help the students stay focused and achieve what is expected from the module. Hence, the objectives and learning outcomes were conveyed to the students. The fifth step is known as Criterion Referenced Test. This test is intended to measure students' skills concerning one or more behavioural objectives. Hence, this module includes interactive lessons with the usage of Interactive Whiteboard like Quick Notes, Example Page and Glossary. It also contains other interactive activities like drag and drop, cross out the wrong answer, fill in the blanks, crossword puzzle and sing along activity. In short, this module caters for numerous learning modalities.

The sixth step is known as Developing Instructional Strategy. This step is intended to draw conclusion on how the instructional activities help achieve the objectives. This module not only includes teacher-led delivery but has also incorporated group-based and learner-centred activities, especially when conducting the experiment "Fun with Science". The seventh step is known as Developing and Selecting of the Instructional Material. This step stipulates the use of specified strategies in developing instructional materials. The module for this study is based on Year Three Science syllabus with the heading "Plants". It is further divided into sub-topics like parts of a plant, woody and non-woody plants, flowering and non-flowering plants and leaves. The graphics and animations inserted in the module were taken from the Smart Notebook software gallery and free science websites. In order to retain and improve the transfer of knowledge, various activities were also incorporated in the lessons. The eighth step involves Developing and Conducting Formative Evaluation. This step allows improvisation to the instructional materials. The evaluation in this step was carried out by interviewing two post graduates in instructional technology who are knowledgeable and have the expertise in instructional design, as well as two science teachers who are content experts. The feedback received was given due consideration, and changes were made accordingly. The ninth, which is the final step, is to Develop and Conduct Summative Evaluation. Here the

module was executed to a group of five Year Three students. After executing this module, these students were interviewed by the researchers. Two educational technologists who were instructional designers and two content experts were consulted. The content experts analysed the content and information design. Having the instructional and curricular knowledge, the teachers gauged the purposes and learning outcomes, content delivery, activities and crossword puzzles. The three elements which were incorporated in the development of this module were information, interaction and presentation designs. When developing the module at the Information Design stage, the contents were organized sequentially according to the target audience and the learning atmosphere.

The design of the content and material were based on Gagne's Nine Instructional Events (Gagne, 1985). The content materials were developed using Smart Notebook software. It is a simple and user-friendly software, and most of the teachers had already acquired the knowledge and skills in operating this software. This software was selected because its functions are similar to Microsoft Word. The materials were taken from the gallery and free science websites. This will also encourage the teachers to create lessons which are interactive in nature. This module introduces the topic and the contents on the first page, which is also the main page.

There are two options available for navigation. One can either touch the arrow buttons or the screen from left to right to go forward and right to left to go back to the previous page. Apart from that, cartoon images were used to attract the attention of these young learners. The target audience will be informed of the objective and the scope of the module that they would be learning. Besides, the knowledge and skills the learners would acquire after exploring the module and completing the activities are made clear through the learning outcomes. This is the second stage of Gagne's Instructional Events where learners are enlightened about the objectives and the learning outcomes. This is done to create a level of expectation among the learners.

In the third stage of Gagne's instructional events, the learners recall their previous knowledge whereby they were posed questions regarding plants available in their surroundings, particularly outside their classroom. 


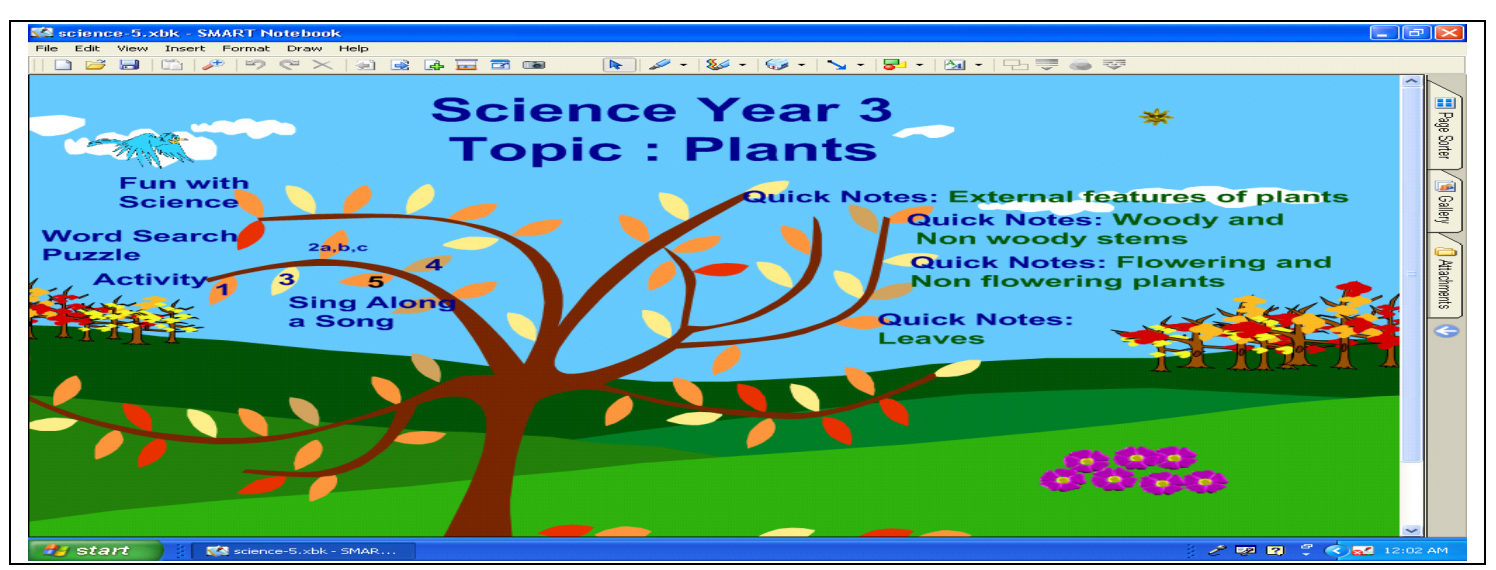

Figure 2. Main page

Quick Notes are prepared for the teachers to go through the contents. Once the page sorter is tapped after going through all the Quick Notes, the learners can now do the activities in the module. There were four sub-topics. The teacher and the learners can choose any sub-topic they intend to explore at any particular time. The fourth stage in Gagne's instructional events presents new contents for the learners such as the text, graphics and animation, which appeal to different kinds of learning styles. In this module, the exercises are in the form of interesting activities. These activities vary from filling in the blanks, conducting an experiment, crossing out the wrong answer and word puzzle. It is a different form of assessment from what they are familiar with, such as multiple-choice questions. Most of the information is available in the Quick Notes. Hence, they have to explore the module to find the answers. The students were motivated because they had the opportunity to search for the answers by navigating the Interactive Whiteboard. Furthermore, these activities would make learning fun and engaging, as well as encourage higher order thinking among the students.

The fifth stage in Gagne's instructional events provide students the assistance in learning, where the teacher will help the students to further explore the topic and provide pictures after Quick Notes, which is the Example page.

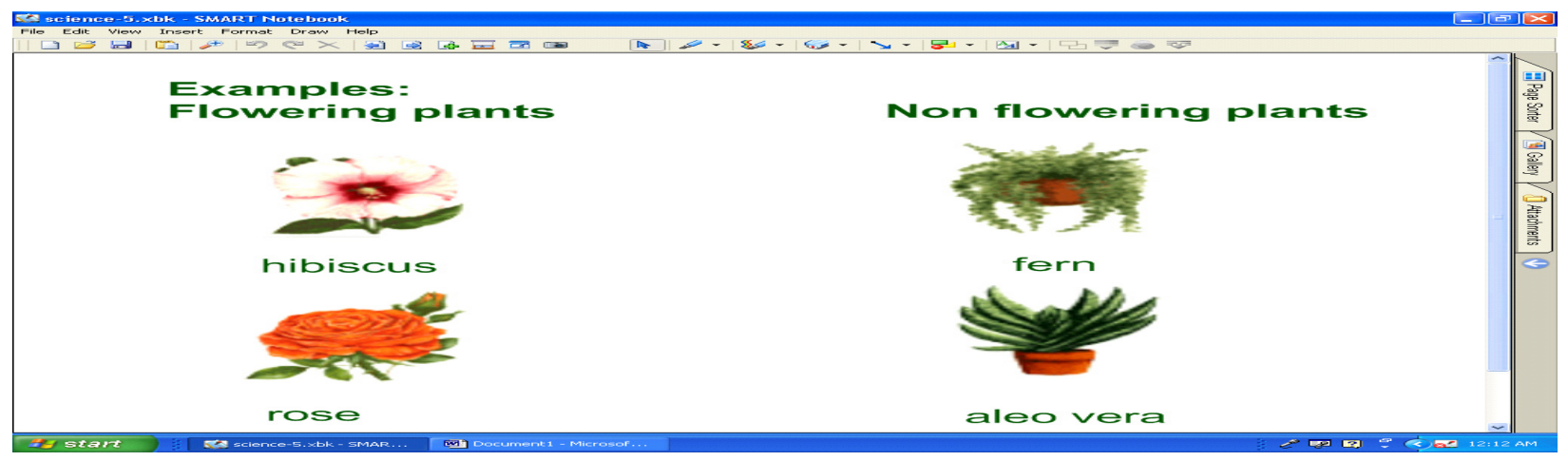

Figure 3. Quick notes

The sixth stage in Gagne's instructional event is to bring forth the students' ability to perform. Students are tested through various interesting activities to see if they were able to understand the lesson better. Activities such as drag and drop, fill in the blanks, crossword puzzle and cross out the wrong answer are some examples.

The seventh and eighth stages are to further assess students' performance respectively. Immediate feedbacks were obtained as the students attempted to complete the activities using the Interactive Whiteboard. It is also beneficial for greater participation of students as it engages them actively in the learning process. Apart from that, the learners were also reinforced with the activities and evaluated based on accurate responses. The ninth stage in Gagne's instructional events is to improve concentration and put across the knowledge acquired. In this stage, the students were given an experiment to be carried out in the classroom; such as "Fun with Science". To do this hands-on activity, the learners were required to appropriately explore the newly acquired knowledge. 


\subsection{Interaction Design}

The interaction design feature focuses on how students should navigate and use the features correctly. To progress from one page to another, the students need to either touch the page sorter arrow key or to touch the screen by moving the finger from left to right in order to move forward or right to left in order to move backward.

Press the Next Page button tho move forward through the Notebook file.

Use the Previous Page button ${ }^{3}$ to move backward.

Figure 4. Example of arrow key

Hence a simple navigation would avoid uneasiness among the teachers and the learners because all the instructions are listed on the screen. A few animated cartoons were inserted to attract students' attention as well as to create an interesting journey of information search. Quick Notes were inserted for each topic for the learners to get relevant information needed from the topic. Pictures were also included to enable the learners to comprehend the topic better. Apart from that, a glossary page was also included in this module for better understanding and faster reference.

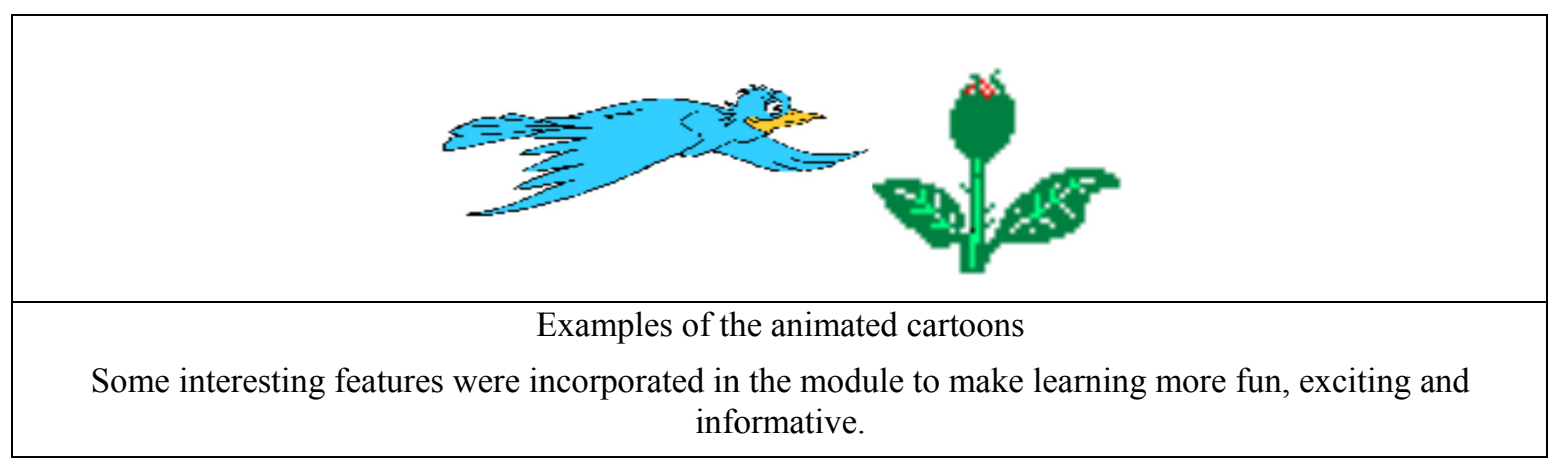

Figure 5. Animations

\subsection{Presentation Design}

In developing and designing this module, it was necessary to ensure the layout and the interface were simple and constant throughout the learning process. The features which were given due consideration are the background colour, font type and size, icons, media elements and layout. At first, a light shade of green was selected as the background colour to match the topic i.e. Plants, but later a white background was used for certain pages because it projected the pictures and texts clearly. The Arial font type size twenty was used for the text. This is because it was visible enough, attractive and suitable for these young learners. All the Information Design experts and the teachers agreed that font type Comic Sans size 12, was suitable for the Fun with Science activity. This is because it was attractive as well as easy to read. As for the instruction for students, Arial Unicode MS size 18 was identified as the most suitable font for young learners. In some pages, basic animated icons were included to gain students' attention. There were also some graphics and two dimensional animation cartoons incorporated in the Quick Notes and in the exercises to further enhance the learning process. This was to ensure learning takes place in a more joyful and meaningful environment.

\section{Evaluation Process}

The process of evaluating and revising was done simultaneously during development and implementation process. These findings by the Information Design experts and the teachers have helped in improving the module.

\section{Conclusion and Implications}

This study focuses on developing a module using the Interactive Whiteboard designed by the researchers. The study also was carried out to determine the appropriateness as well as the shortcomings of the module. It addresses three components which are information, interaction and presentation design as mentioned by Kristof and Satron (1995).The overall feedback gathered from the instructional technologists and content experts were very positive. They also found this module attractive, beneficial and engaging. Therefore, this module is appropriately 
tailor-made to be implemented in primary schools based on the feedback obtained from the experts. On the whole, this paper assist teachers in making vital decisions pertaining to appropriate characteristics that are needed for integration on Interactive Whiteboard in a classroom. This is further echoed by Higgins, Beauchamp \& Miller (2007) and further exemplified by Wood \& Ashfield (2008) that the focus and capability of the teacher who is arbitrating the interaction with students is the utmost decisive feature in producing the desired effect in the integration of Interactive Whiteboard.

\section{Recommendation}

A possible area for future research is to analyse feedback from students which will enable improvements to be made on the content and materials used. This is also necessary to enhance this module further from a student perspective and to conduct a study on students' performances in other subjects. This will help to observe if there are any improvements in integrating this kind of technology in their classrooms.

This finding is supported by Bhola (1990) that summative evaluation is conducted to ensure the minimum level of knowledge, skills and attitudes has been attained by the intended learners.

\section{References}

Beeland, W. B. (2002). Student Engagement, Visual Learning and Technology: Can Interactive Whiteboards Help? Retrieved August 5, 2012, from http://chiron.valdosta.edu/are/Artmanscrpt/vollno1/beeland_am.pdf

Bhola, H. S. (1990). Evaluating "Literacy for development" projects, programs and Campaigns: Evaluation planning, design and implementation, and utilization of evaluation result (Vol. xii, p. 306). Hamburg, Germany: UNESCO Institute for Education; DSE [German Foundation for International Developement]. Retrieved August 5, 2005, from http://www.sil.org/lingualinks/literacy/ReferenceMaterials /GlossaryOfLiteracyTerm/WhatIsEvaluaton.htm

Chandler, M. A. (2005). From blackboard to smartboard. The Star. Malaysia.

Cox, M. (2008). Students' formal and informal uses of digital technologies: Implications for teachers and schools. Keynote address. The Australian Computers in Education Conference. Canberra. Retrieved from http://www.acec2008.info/ confpapers/res u Its. Asp

Dalbir, S., Ridha, O., \& Azfar, A. (2010). Low Cost Interactive Electronic Whiteboard Using Nintendo Wii Remote. American Journal of Applied Sciences, 7(11), 1458-1463. http://dx.doi.org/10.3844 /ajassp.2010.1458.1463

Dick, W., \& Carey, L. (1990). The Systematic Design of Instruction (3rd ed.). USA: Harper Collins Publishers.

Gagne, R. M. (1985). The conditions of learning (4th ed.). New York: Rinehart \& Winston.

Hackling, M., \& Prain, V. (2006). Primary connections: Stage 2 trial research report. Australian Academy of Science.

Hashimah, M., Yunus, Z. I., \& Raper, G. (2007). Malaysian Primary Teachers' Classroom Practice of Teaching and Learning Science. Journal of Science and Mathematics Education, 27(1). http://dx.doi.org/10.1080 $/ 17439880701511040$

Higgins, S., Beauchamp, G., \& Miller, D. (2007). Reviewing the literature on interactive whiteboards. Learning Media and Technology, 32(3), 213-225.

Ismail, Z. (2002). Pendidikan Bertaraf Dunia: Ke Arah Pembestarian Dalam Proses Pengajaran dan Pembelejaran. Retrieved September 10, 2005, from http://www.tutor.com.my/tutor/motivasi/artikel /pendidikan bertarafdunia/htm

Jamerson, J. (2002). Helping All Children Learn: Action Research Project Longfellow Elementary School Muncie, Indiana. Retrieved April 13, 2002, from http://www.smarterkids.org/research/paper15.asp

Jones, S., \& Tanner, H. (2002). Teachers' interpretations of effective whole-class interactive teaching in secondary mathematics classrooms. Educational Studies, 28(3), 265-274. http://dx.doi.org/10.1080 /0305569022000003717

Kearney, M. (2007). Exploring pedagogy with interactive wbiteboards: A case study of six schools. Retrieved June 5, 2008, from http://wwvv.ed-dev.uts.edu.au/teac hered/research/iwbproject/pdfs/

Kristof, R., \& Satran, A. (1995). Interactivity by Design. Mountain View, CA: Adobe Press.

Murcia, K. (2007). Science for the 21 century. Teaching for scientific literacy in the primary classroom. Teaching Science, 53(2), 16-19. 
Norrizan, R. (2002). Reinventing Education through the Smart School Flagship Application. Multimedia Development Corporation. Retrieved July 19, 2005, from http://www.symbiosisonline.com /dec02_reinvent.htm

Riel, M. S., \& Hitt, A. (2002). School change with technology: Closing the digital divide. Information Tecbnohgy in Cbildbood Education Annual, 147-179.

Rogoff, B. (1995). Observing sociocultural activity on three planes: participatory appropriation, guided participation, and apprenticeship. In J. V. Wertsch, P. Del Rio, \& A. Alvarez, (Eds.) Sociocultural Studies of Mind (pp. 139-164). Cambridge, Cambridge University Press. http://dx.doi.org/10.1017 /CBO9781139174299.008

Shenton, A., \& Pagett, L. (2007). From bored' to screen: the use of the interactive whiteboard for literacy in six primary classrooms in England. Literacy, 41(3), 129-136. http://dx.doi.org/10.1111/j.1467 $-9345.2007 .00475 . \mathrm{X}$

Smart Technologies. (2004). Interactive Whiteboards and Learning: A review of Classroom Case Studies and Research Literature. Retrieved October 15, 2006, from http://education.smarttech.com/NR/rdonlyres /30258C60-24D0-43D5-A1D2-BDE1A93B6F93/0/InteractiveWhiteboardsAndLearning.pdf

Smith, H. J., Higgins, S., Wall, K., \& Miller, J. (2005) Interactive whiteboards: boon or bandwagon? A critical review of the literature. Journal of Computer Assisted Learning, 21(2), 91-101. http://dx.doi.org/10.1111 j.1365-2729.2005.00117.x

Termit, K., \& Abdul, R. (2012). Secondary Students perspectives on the use of the Interactive Whiteboard for teaching and learning Science in Malaysia. Journal of education and Practice, 3(7).

Wood, R., \& Ashfield, J. (2008). The use of the interactive whiteboard for creative teaching and learning in literacy and mathematics: A case study. British Journal of Educational Technology, 39(1), 84-96.

\section{Copyrights}

Copyright for this article is retained by the author(s), with first publication rights granted to the journal.

This is an open-access article distributed under the terms and conditions of the Creative Commons Attribution license (http://creativecommons.org/licenses/by/3.0/). 